\title{
STABLE MOBILITIES AND MOBILE STABILITIES IN RURAL ESTONIAN COMMUNITIES
}

Raili Nugin, Kadri Kasemets ${ }^{1}$

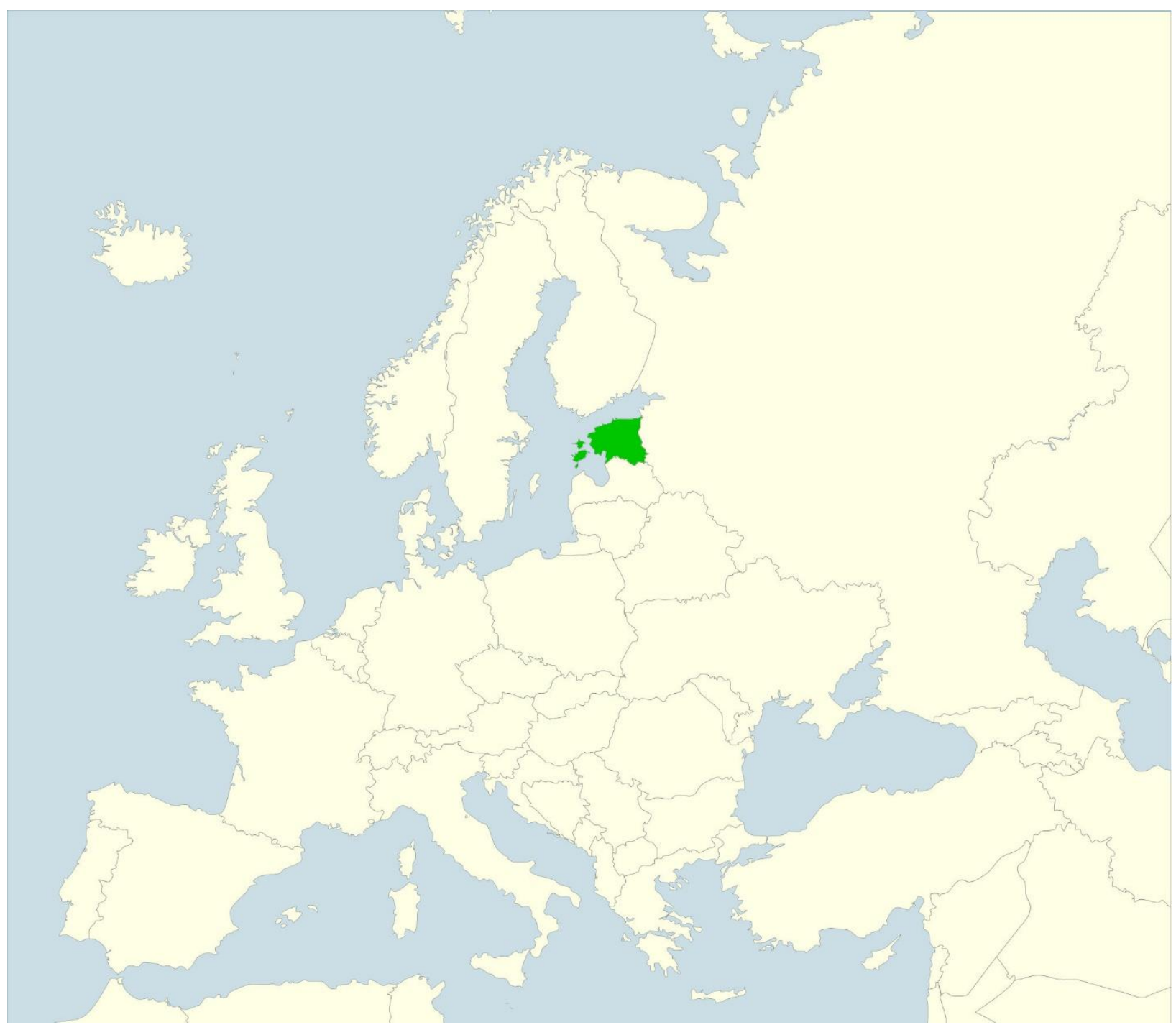

1 Raili Nugin, PhD., e-mail: raili.nugin@tlu.ee, ORCID: 0000-0003-1428-5724; Kadri Kasemets, PhD., e-mail: kadri.kasemets@tlu.ee, ORCID: 0000-0002-9527-3129, Centre for Landscape and Culture, School of Humanities, Tallinn University, Tallinn, Estonia 
Abstract: By analyzing the relations of communities and places in sparsely located rural areas, this article argues that rural community is not a stable unity tied to a place, but a phenomenon closely tied to its members' connections to the interdependent concept of urban/rural, especially in terms of their mobility practices. In this study, the new mobilities paradigm was applied to reveal how everyday relational and routine aspects connected to material, structural, socio-cultural and economic conditioning dynamically intertwine to form a rural community. The analysis is based on three regional case studies in Estonian sparsely populated areas, which are diverse in terms of geographical location, demographic composition, type of settlement, history, and welfare conditions. By using qualitative in-depth interviews with people $(\mathrm{N}=60)$ who were involved with the locations, the article analyses everyday mobilities in these communities, especially in terms of interrelatedness to structural, social and material factors. The study has brought out interrelated themes that are connected to the use of rural representations in terms of individual and social self-reflection, the importance of social and material infrastructures, and the dynamics of these borders in communities and shaping community relations.

Key words: everyday practices, new mobilities paradigm, rural community, sparsely populated areas, qualitative research, Estonia

\section{Highlights:}

- New mobility paradigm is useful when contextualizing dynamics of communities in sparsely populated areas;

- Individual and collective representations of rurality do not coincide with the mobile lifestyles of the rural inhabitants;

- Mobile people still make active use of strong symbols of stable and peaceful rurality in establishing their identities and making sense of everyday lives;

- Different understanding of what constitutes the rural may cause tensions, but may be a base for establishing new networks and community dynamics;

- Mobile communities need stable materialities to exercise community identity and to shape socio-economic relations and mobilities.

\section{Introduction}

In recent decades, the development of mobilities has affected many aspects of everyday lives both in rural and urban areas. Movement of people, information, ideas, and capital has urged a number of theorists to scrutinize how these mobilities have affected the notion of community in the context of locations undergoing change, as traditionally, places have formed an important core in community conceptualization (Irwin, 2016). This article asks how community in rural Estonia has been affected by mobilities, examining and contextualizing 'community' as a concept in the background of different contemporary structural, social, cultural, and political conditions. To this purpose, three rural areas in Estonia were chosen, and participant observation and in-depth interviews with 60 informants were conducted during the period of 2017-2020. While looking at community, we also paid attention to spatial relations of the rural and urban. By analyzing the relations of communities and places in sparsely located rural areas, this article aims to demonstrate that rural communities are not stable unities tied to a place. The analysis shows that communities depend on and rely upon mobilities and that mobilities can empower communities as well as undermine them.

To date, many authors have lamented about the loss and weakening of community ties (Putnam, 2000; Bauman, 2001; Blackshaw, 2010, p. 101). It has been argued that fragmented social groups have replaced stable communities in the lives of people, and during the contemporary era of 
'networked individualism,' people can choose the time and amount of their commitment, while playfully entering and exiting different communities (Castells, 1996, p. 415; Hampton \& Wellmann, 2001; cf Barrett, 2015, p. 183). The theorists discussing the decreasing importance of social ties commonly refer to urbanized society and describe an urban life style, wherein the individual is anonymous and isolated from the whole without meaningful community relationships (Blackshaw, 2010, p. 98). As urban environments are increasingly becoming anonymous (Bauman 2001), the 'real' community is often imagined to exist particularly in rural areas as 'the rural' has been commonly depicted as a haven of traditional values and close-knit communities (Woods, 2011; Mettenberger \& Küpper, 2019; Nugin 2018).

However, the impact of mobile lifestyles on communities has not gained enough attention in rural studies. If addressed, it has been usually suggested that outmigration and mobile lifestyles have disempowered rural communities (Annist, 2011). Though rural communities have been one of the central themes also in studies of rural geography (Roche, 2002, p. 825), they are often still depicted in a sedentary way. Rural community mobilities have been examined previously from a pragmatic and strategic perspective, for instance through accessibility (Delbosc \& Currie, 2011), community involvement (Mettenber \& Küpper, 2019), or social innovation (Bossuet, 2006). Less attention has been paid to how mobile lifestyles empower or mobilize communities and which mobility practices contribute to rural community persistence (cf Milbourne \& Kitchen, 2014; Mettenberger and Küpper, 2019). This article aims to fill this gap by analyzing how mobilities shape and are shaped by community relations.

In the analysis, we apply the new mobilities paradigm (Sheller \& Urry 2006), which treats communities in a dynamic way, focusing on the interrelatedness of movement, social relations, and representations. Under the auspices of this paradigm, mobilities are defined as culturally and socially produced motion (Sheller \& Urry, 2006). Our aim was to confront the discourse of sedentary community and to add a more complex view to the mobile character of community. The new mobilities paradigm is not a comprehensive set of theories, but rather a way of asking research questions and uniting research agendas, which have been previously analyzed separately. Thus, in addition to examining different physical movements and flows, various movements of ideas, relations, and rhythms that influence relational meaning-making and creation of identities are studied (Creswell, 2010; Cresswell, 2012). Such relational micro-level topics involve concepts reflecting subjective interrelated place connections, such as belonging, sense of place, and the meaning of home (Frello, 2008). The sense of place, for instance, is the fusion of many routines and habits related to body, time, and space, whereas everyday movements in place and spatial conditions influence the emergence of different types of belonging connected with different place attachments (Fallov, Jørgensen \& Knudsen 2013, p. 469-470). In our analysis, we emphasize the relational perspective in the new mobilities paradigm, as multilocality is relational and dynamic, both in terms of physical and mental perception of the rural (Rodman, 1992). We argue that community is affected both by symbolic representations of urban and rural as well as by everyday movements in between rural and urban spaces. This approach to the concept of community enables a better understanding of community dynamics and thus also can be a source for a more adequate regional and rural policy.

The article starts off with a brief overview of the Estonian context, which will be followed by a glance at theoretical literature that views communities through the new mobilities prism. After introducing the particularities of the research sites, the methodology and data will be described, presenting also the way the analysis was conducted. This will be followed by an analysis section, which is divided into three different subsections, each describing the complex interrelations of mobilities in the rural communities interconnected to structural, social, and material place-based dimensions.

\section{Estonian context}

Estonia is a small country $(45,227$ square kilometres) with only 1.3 million inhabitants, and with one of the smallest population densities in Europe. Estonian rural regions have experienced turbulent changes after the fall of the Soviet empire in 1991 and re-establishment of the Estonian state, when agriculture was de-collectivized according to a top-down principle and individual farm 
enterprises were prioritized over big-scale farms (Alanen, 2004, p. 5-6). Though the rural areas enjoyed considerable social and material welfare during the late Soviet era (Kurg, 2019), the transformation years during the 1990s and 2000s and the dissolving of collective farms had quite a dramatic impact both socially and demographically. The new spatial planning policies brought along abandoned housing, unmaintained land, and underused infrastructure. The new economic activities emerged in larger urban regions rather than in rural areas (Raagmaa \& Stead, 2014). Similar to other post-socialist countries, unemployment and wave of bankruptcies hit many rural regions hard and thus, post-communist rural areas have been depicted as losers of the transition (Alanen, 2002; Kay, 2012, p. 66).

Insecurity during the agricultural transformation caused increasing out-migration of the rural inhabitants to urban areas. After Estonia joined the European Union in 2004, the financial situation improved, yet many new regulations emerged that caused confusion and changed everyday practices and traditions. For instance, new regulations on dairy production caused a gradual decline in small-scale dairy farms, as they were not capable of meeting all these regulations. However, the EU's regional and rural policy support (Granberg, 2004) led to the development of a citizenship who could build a governance-based policy in rural management (Ruutsoo, 2004). Rural areas have been also influenced by different waves of municipal reforms. The most recent one with major changes was passed in 2017, merging together different small municipalities to form bigger ones with higher population numbers and thus a more substantial financial base (Sepp \& Noorkõiv, 2017).

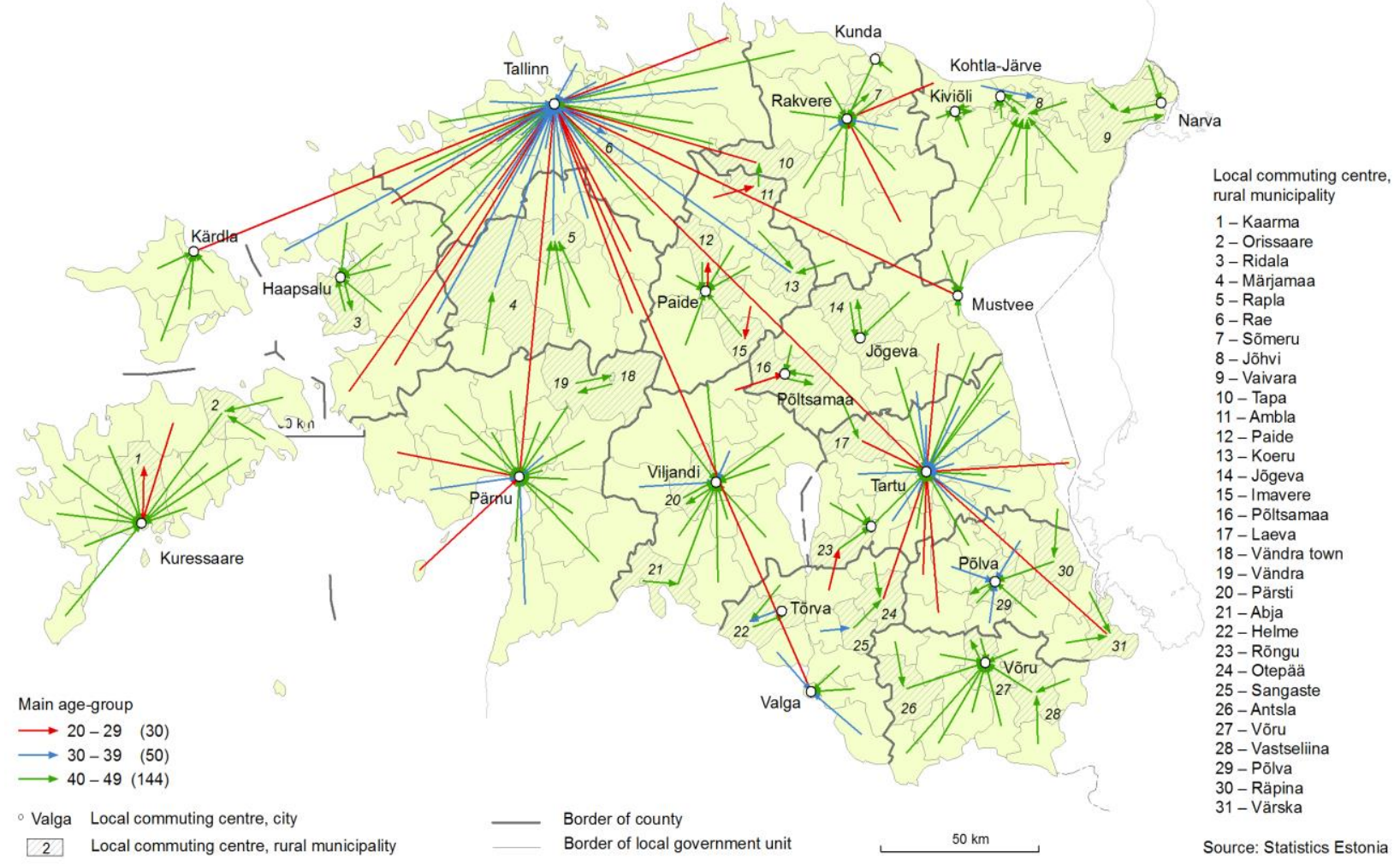

Fig 1. Job commuting between localities by age group in 2011 (Valgma, 2013).

Recent developments in transportation and the spread of suburban regions (cf Nugin \& Palang, 2020; Kasemets et al. 2019) have changed both mobility practices and social structures of the localities. Currently, the population is highly concentrated around the capital. Forty percent of the population lives in Tallinn, and forty-five percent of the workforce have jobs there (Statistics Estonia, RL011). Further, more than 60 percent of the GDP is produced in Tallinn and its surrounding Harju county. These numbers indicate that Estonia is a country which has a high urbanization rate (mainly accelerated after the dissolution of the Soviet Union), but also a high degree of work-mobility. 75,000 people travel to Tallinn for work (with a population of 426,538) on daily basis (Tamm \& Nergi, 2018). Commuting for work is rather common in other regional centres 
as well. Figure 1 illustrates working mobilities of Estonia. While in 1997, 81\% of people worked at the same municipality they lived in, by 2017 , this number had diminished to $63.1 \%$. In rural areas, the respective numbers are far more dramatic, being 64.6\% in 1997 and 35.1\% in 2017 (Statistics Estonia, TT234). After the municipal reform in 2018, when several parishes were merged together, this number somewhat increased (41.1\%). Yet, it should be noted that the biggest parish Saaremaa's area is 2700 square metres and commuting within the parish might also take hours. In other words, the declining numbers of commuting do not reflect necessarily that the commuting has diminished.

\section{Theorizing (im)mobile communities}

With the recent rise in academic interest in mobilities in social and spatial science, the conceptualization of mobilities has diversified (Cresswell, 2010). In the following, we will elaborate on our understanding of mobilities using this article, as the research findings depend on how mobility is operationalized (Kaufmann et al. 2004, p. 749). Along with Mimi Sheller and John Urry, proponents of new mobility paradigm, we argue that mobilities should be examined in their 'fluid interdependence' (Sheller \& Urry, 2006, p. 212) and therefore, places and social structures around locations in relation to mobilities become just as important as the act of movement. Besides, not only the physical moving is relevant, but also the meanings, representations (Cresswell, 2010, p. 552) and history of mobilities (Cresswell, 2012, p. 645) gain relevance in this research. Though the symbolic and virtual dimensions of mobility become significant (the movement of ideas, virtual connections) in mobility research, mobilities are simultaneously materialized and localized (Sheller \& Urry, 2006). That is, material and local structures and everyday lives are influenced both by physical mobilities just as well as by movements which are imagined or virtual. As Sheller and Urry note: 'Places are about relationships, about the placing of peoples, materials, images, and the systems of difference that they perform' (Sheller \& Urry 2006, p. 214).

All these relationships are inherently social - mobility is not only about moving, but also about what meaning this movement has in social circles, how it is enhanced by social relations or how it disrupts social relations. Mobility can be defined as a resource. Kaufmann, Bergman, and Joye (2004) have coined the term 'motility' to signify the potential of mobilities and the social hierarchies they create, suggesting that the potential to move can simultaneously be a form of inequality. According to them, 'motility refers to both vertical and horizontal dimensions of social position' (Kaufmann et al., 2004, p. 754). Moreover, mobility is just as much about moving as it is about decisions to stay put; mobility is also about islands of waiting during the movements (Cresswell, 2010, p. 552; Cresswell, 2012, p. 645; Kaufmann et al., 2004, p. 750; Halfacree \& Rivera, 2012, p. 92). In other words, phenomena which are not often associated with mobilities, or even considered opposing ones, are all connected, depend on, and interrelated with different forms of mobilities. One of such concepts is stability - mobilities can be stable just as well as stabilities can be on the move (Sheller \& Urry, 2006, p. 214, Halfacree, 2012, p. 211). Thus, it would be short sighted to exclude stable aspects of everyday lives from mobility research (Bell et al., 2010, p. 211). Everyday mobilities shape and create new materialities, and places are produced and reproduced by socio-political flows, actions, and engagements (Hunt, 2019, Halfacree \& Rivera, 2012 , p. 105). The changing symbolic meanings of dwelling places affect also the non-human natural environment (Halfacree \& Rivera, 2012, p. 105-108; Maclaren, 2018). In a similar vein, changes on the administrative level mould norms and representations, affecting thus also sociomaterialities of locations (Ellingsen, 2017).

(Rural) community is commonly left aside from mobility research and often described with expressions referring to security, stability, belonging, rootedness, and immobility (Blackshaw, 2010, p. 96, Goodwin-Hawkins, 2015, p. 176). Communities in rural areas are often depicted as stable repositories of desired values in an otherwise mobile world (Shucksmith, 2018, p. 263). While the urban is on the move, the rural is conceptualized as standing still (Goodwin-Hawkins, 2015, p. 167; Nugin, 2018). It is something to be sustained and preserved rather than developed (Shucksmith, 2018), and depicted as not active, but rather, to be acted upon (Bell et al., 2010, p. 206). 
A closer look reveals that all these social and cultural constructs about rural communities entail different paradoxes. First, the longing for the stability brings urban dwellers and second homeowners to the countryside, thus enhancing mobilities and potentially blurring the borders of the urban and the rural (Hidle et al., 2010, p. 149). Second, stable communities are depicted as inclusive, but in order to survive as stable, should be exclusive (Shucksmith, 2018, p. 167). Third, though communities provide a sense of security, being part of them may mean lack of freedom (Bauman, 2001, p. 4) and being tied to a place may become a liability rather than an asset (Bauman, 2001, p. 110). Does all this suggest that rural communities are under threat? According to different researchers, the urban 'incomers' do not necessarily bring forth a homogenization of urban/rural space; rather, this process creates a new hierarchy of space (Hidle et al., 2010, p. 150-152, Mormont, 1990). Rural communities are dynamically changing with the rest of the world due to increased mobilities; they are on the move, but not inescapably dissolving. Mobilities should not be treated as threats to communities, but rather, as means of connectivity and networks within communities (Hidle et al., 2010, p. 141). These networks form not only within and in between communities, but also on regional and administrative levels. Local village organizations gain know-how, instructions, and financial support from regional and state levels, and urban level administrators expect local initiative for structural changes in places. Neoendogenous theories see such rural and urban dichotomy rather as a continuum (Meador, 2019) because they try to combine bottom-up planning with top-down planning, to include local place based internal and external networks (Navarro et al., 2016).

Rural communities are increasingly dependent on migration and mobilities. To date, much research has focused on different groups in rural areas which are defined via migration strategies (in-migrants; second home owners; out-migrants; native population). However, it is becoming increasingly difficult to classify these groups and often, one person can shift back and forth between all these groups, making these distinctions highly arbitrary. Even though people sometimes label themselves as belonging to one group or another (Creamer et al., 2019, p. 950, 954), the lines between the groups keep shifting. This does not mean we have to ignore migration to and from the rural areas in research topics. Rather, we should treat migration not as an act of movement, but a process preceded and followed by different biographical developments; we should take the biographical perspective into the focus of migration research (Halfacree \& Rivera, 2012, p. 92; Coulter et al., 2016, p. 360). For instance, residential moves are regarded as a result of life-course changes, i.e., careers, planning a family, long-term educational motivations, or kinship relations (Coulter et al., p. 356-356; Cohen, Duncan \& Thulemark, 2015). Halfacree and Rivera (2012, p. 97), thereby emphasizing that migration does not concern only representational socio-cultural construction for reasoning the move, but additionally contains relational content. Biographies change with time and space, and so do the meaning and role of migration in biographies (Halfacree \& Rivera, 2012, p. 106). Thus, the biographical perspective is important in analyzing mobility aspects in communities (cf Jetzkowitz et al., 2007).

Migration is not necessarily a smooth process and can sometimes cause tensions. Several researchers have noted that often, middle class in-migrants take an active role in shaping the local community activities, making community-building often class-specific and potentially increasing inequalities (Halfacree \& Rivera, 2012; Creamer et al., 2019). According to Savage, Bagnall, and Longhurst, for many middle class people rural places have become 'sites to perform identities' (2005, p. 29; Savage 2010) and this kind of social involvement in community activism enhances place attachment and feelings of belonging (Tomaney, 2015, p. 508). This activism is strongly based on the representations of the rural, as the incomers are actively trying to perform and enact their ideas of the rural (Edensor, 2006, p. 484; Woods, 2010). These representations are strong motivators for both moving to the countryside as well as becoming socially active there. Community is also performed through different daily tasks and routines (Woods, 2010, p. 835), though sometimes mismatches emerge between the imagined rural life and actual rural practices (Halfacree \& Rivera, 2012, p. 101-102, 106).

People develop diverse types of place attachment depending on their access to mobility, and mobile people may have a different sense of place (Gieling et al., 2017, p. 237). Dwelling itself has become mobile (Halfacree, 2012, p. 216) and sometimes, the experience outside the home community helps to develop reflexive place identity (Shucksmith, 2018). Mobility affects also 
community borders, which are shifting and blur and vary within the same geographical location (Cresswell, 2014, p. 718). Thus, mobilities potentially shape all kinds of phenomena that are tied to communities, which are complex interplay of interests, norms, and identity (Barrett, 2015, p. 194).

\section{Data and methodology}

The article is based on three case study regions in Estonia, which are diverse in terms of geographical location, demographic composition, type of settlement, history, and welfare conditions. The research sites are situated in south-east Estonia (Region A), west Estonia (Region $B$ ) and north Estonia (Region $C$ ). The first two (A and $B$ ) can be considered rather peripheral areas, as the drive to Estonian capital Tallinn takes three (A) or four (B) hours. By contrast, the commute to Tallinn from the third sample area takes approximately forty minutes and thus, many people in the area are connected with the capital city via the job or education market, and rely on Tallinn in their daily shopping or in the need of medical care. A and B people's lives are intertwined with the closest regional centres (towns). In the case of $A$, the regional centre (population 5,500 inhabitants) is situated (depending on the particular village) 6-10 kilometres away; in the case of B, 30-40km away (population of the town 13,300 inhabitants). In addition, A has a good railway connection (50 min) with Estonia's second largest town Tartu, which is situated $55 \mathrm{~km}$ away and has 100,000 inhabitants. B is situated near popular tourist destinations, which attract tourists both from home and abroad. The nearby town has many spa hotels and a seaside. $A$ and $C$ are not particularly popular as tourist destinations, apart from occasional local tourism and second home-owners who come during the summer.

Each researched region experienced structural changes after the aforementioned municipal reform in 2017. After merging with neighbouring parishes, $B$ and $C$ regions are now part of the two largest municipalities in Estonia $(B=33,000, C=23,000$ inhabitants). $A$ is a somewhat smaller parish - with 14,000 inhabitants. The structural rearrangements, however, took place also before the major reform. For instance, two years before the major reform and subsequent merger, region $B$ had merged with two neighbouring parishes (B parish previously with 800 inhabitants formed now parish which had 7,000 inhabitants). These structural reordering processes are important to mention in the context of this particular article, as we focused on regions that at the moment are not necessarily institutionally defined as one administrative region. Yet, historically, these regions can be considered as units, though perhaps drawing such borders (especially during the mobile times) is, no doubt, arbitrary. The researched areas consisted of different villages. In the case of $A$, people predominantly from two villages were interviewed; in $B$, five villages; and $C$, three villages. The villages were unevenly populated, with the smallest ones having 35 inhabitants and the biggest 300 .

The researchers have made numerous visits to the locations in different time periods during the field work and spent some time living there. This also involved using the local infrastructures (transportation, shops), attending local events, and observing the movements in the region during different seasons. Both researchers are in one way or another tied to the place either using it as a second home or having a close relative living there. On the one hand, this has given the authors a deeper research perspective in understanding different processes in time and getting better access to research subjects. On the other hand, this entails risk of missing some issues that an outsider perspective would enable. However, knowing local infrastructures, transportation possibilities, heritage sites, village spatial organizations, shopping options, or closeness of medical care, helps in many ways both in gathering research data, asking follow-up questions, as well as analyzing the data.

In three areas, 51 in-depth interviews with 60 informants were conducted $(\mathrm{NA}=21, \mathrm{NB}=19$, $\mathrm{NC}=20$ ). The average birth year of the informant was 1967 (for detailed information, see figure 2), and 24 male and 36 female informants were included. The interviews were conducted during the period of 2017-2020; the average interview lasted for an hour, with the longest ones taking up to two hours. Most of the people were permanent residents except for nine people who were tied to the location in other ways (second home or kinship). The interviews were semi-structured with slightly varied questions, depending on the particular person and interviewer. Many 
interviews were structured as biographical interviews, starting with the life-course approach (Jetzkowitz et al., 2007; Halfacree \& Rivera, 2012, p. 92; Coulter et al 2016, p. 360) and then moving to the questions of everyday practices, place attachment, and belonging. The rest of the interviews followed a different approach, starting with stories of informants' involvement in the area and everyday arrangement that reflected the place attachment of the interviewees. These questions were followed by questions about the use of social and physical infrastructures and individual involvement and reflection about community activism. Thus, though some questions were formulated through a social prism and others were spatially prepared, the interviews reveal similar research data.

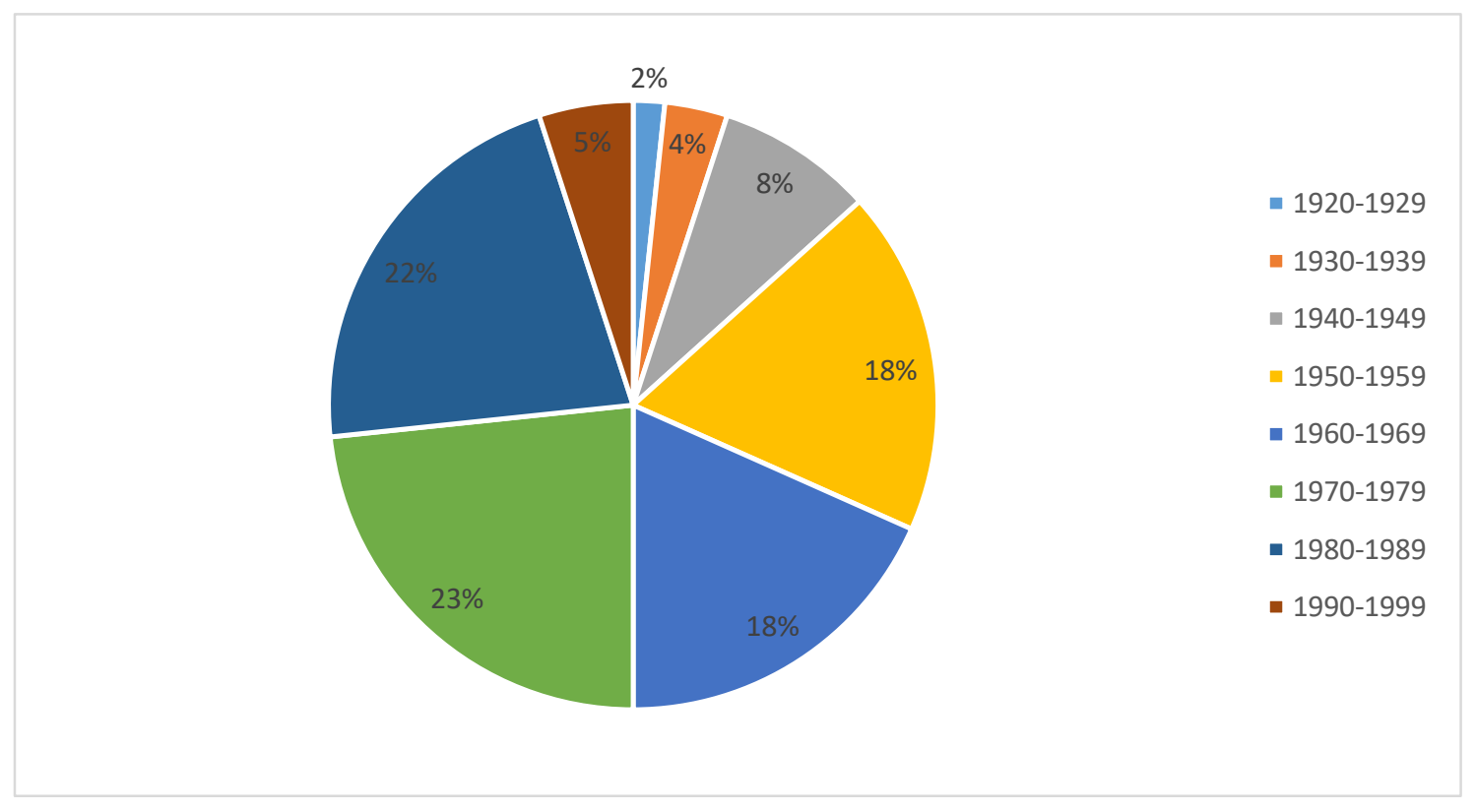

Fig 2. Age distribution of the sample [year of birth]. Source: own research

While we aimed for diverse and heterogeneous sample, we are aware that we predominantly interviewed people who were involved in community life or were socially active in one way or another. We compiled our sample by looking at the web site of a village activists' organisation, but also via social connections and the snowball method. To compensate for the elite-prone sample, we also approached some people who were socially disadvantaged, though this part of the sample was proportionally very small. In our sample selection, we also considered the level of involvement with the location, including second home-owners, commuters, summer residents as well as those who have shifted their status from one to another.

The interviews were recorded and transcribed verbatim. After that, both researchers read through the interviews multiple times and coded the interviews separately, sharing the codes then with one another and discussing the research data thoroughly. For coding, NVivo 9 was used. For analysis, the directed qualitative content analysis method was used (Hsieh \& Shannon, 2005), in which the research data is analyzed following a specific question or theory. In the case of this article, the new mobilities paradigm was used as a base theory against which the data was coded. The interviews were critically read from the standpoint of the new mobility paradigm and communities, asking in each case how the phenomena the informant explained (everyday practices, future plans, living conditions, arrangement of the village) was connected with community and mobilities and how these practices could have been influenced by mobilities or, vice versa, could affect mobility practices. In other words, we used a relational approach in analyzing our data, focussing on the relation of mobilities, representations, material dimensions, social structures, and social hierarchies. During the analysis, three main different topics emerged, according to which the analysis section of the article is organized. Each topic describes the complex interrelations of mobilities in the rural communities interconnected to structural, social, and material place-based dimensions:

(a) Paradoxes of the representations of the rural 
(b) Social and physical infrastructures shaping mobilities and communities

(c) Dynamics of social and material borders in communities

These themes allowed the community to be examined in relation to mobilities, including also the aspects of materialities, symbolic representations, and individual identities in a biographical perspective.

\section{Analysis}

\subsection{Paradoxes of representations of the 'rural' and 'community'}

Examining the interviews, we noticed how representations of rurality were strongly intertwined with everyday practices and community relations. In some cases, representations of rurality can shape the biographical decisions and mobilities of everyday lives. One of such examples is the story of Eeva ( $F$ from B, 1984) $)^{2}$, who was born in B area, but moved a lot during her childhood between different villages around the area and lived altogether in four places before the age of 15. However, during all these (mobile) years, she spent her summers and weekends at her grandmother's place, creating some kind of stability in her mobilities. After the age of 15, she lived in different urban environments while studying and starting her working life and creating a family on her own. Yet, she decided that city life was not for her. When asked about the reasons, mobility was something that came up as a metaphor of urbanity.

In the morning, you take your kid to kindergarten, then you go to work, then you have to pick up the kid, then to shop, then home. It was... somehow so brutal, that it quickly started to get on my nerves... (Eeva).

Her characterizing of urban life continued that it was "so sad" to live life driving to work and home for hours and in the evening "sit on that couch and it will all start all over again in the morning. That... you don't have a goal in life somehow...". When describing her life in the city, she used strong metaphors, which referred to "endless suffering". Yet, after moving back to the countryside she did not get more time on her hands. She commuted daily to work $30 \mathrm{~km}$ away and in addition, spent a lot of time seasonally at her late grandmothers' place $13 \mathrm{~km}$ away from home (she used her house as second home). Sometime after moving back, her partner started a periodic study programme in a place which was six hours drive from home. Working in forestry now (previously he worked in the finance sector), her partner's days often consisted of driving around a vast area. During the interview, she mentioned several times that she would like to be involved with different activities (walking in the woods, going to the theatre), but just does not have time any more. In short - interestingly enough - for Eeva, a busy life in the city felt differently than a busy life in the rural area. For a bystander and listener, there seems to be a contradiction of everyday practices and representational depiction of rural and urban in her narrative. The hours she spent driving had not changed much and she lived in an apartment building also in the rural area. Yet, these features did not bother her in her rural life, though the very same occurrences were the ones she despised in urban life. The notion of the speed in the city and slow motion in the countryside was expressed by a number of other informants as well. Joonas ( $M$ from $B, 1975$ ) also referred to city life as being such a "hassle and trouble" though he, too, had a hard time finding a spare moment in the midst of his working life and managing a rural household.

Another example of how representations of rurality can become strongly intertwined with everyday practices and community relations, are Kätlin's (F from C, 1985) opinions about rurality. She felt that the urban and rural borders are shifting. When asked how this expresses itself in everyday life, she answered that unlike in the past, today the village road is busy with cars and you cannot walk peacefully there anymore. It is noteworthy that Kätlin's first association with rurality is walking (slow motion), which is disrupted with urban elements - many cars moving on the roads (fast motion). In other words, moving, its pace and frequency is something that defines rurality and urbanity for her. The metaphor of moving kept coming up in other different interviews as well. Luisa ( $F$ from B, 1991) described how during the winter, when tourists are not frequent

\footnotetext{
${ }^{2}$ In the brackets first letter indicates gender, second studied region, and third birth year of the interviewees.
} 
guests in the nearby town and the streets are empty, 'you wonder why the hay rolls are not flying around'. By this expression, Luisa hinted that streets without movement can become rural, as hay rolls for her represented rural landscape.

Yet, this does not mean rural representation means immobility. Rather, it signifies mundane mobilities (Edensor, 2007). For Ivo (M, from A, 1944), the emergence of cars and fast mobilities has in a way killed community communications and coherence, as people do not walk by anymore:

Yes, I don't know these people [living in the same village]. It is interesting, during old times, people communicated, walked on foot, passed your house and stepped in to have a word with you. But now, people are living separately on their own, no communication of that kind anymore. (Ivo)

In short, it is not about moving, it is the way people move which becomes important. It is thus specific kind of movement that is often related to rural life and this may also influence everyday practices and community relations.

Often, freedom of movement is a notion which is considered as part of the representation of rural life. Kätlin was worried that contemporary people or those who have moved to countryside from urban areas 'don't actually understand what rural life means.' For her, rural life was about moving freely without paying attention to borders, children running around, through neighbours' yards and across fields. Yet, she described problems that emerged with her neighbours due to her kids running freely around. Kätlin did not argue for dissolving private borders. Rather, she hoped that accepting occasional free movement was part of good community relations. For many informants, rural life was about moving and freedom to move, yet on the other hand several also pointed out the need for privacy and that you have 'a territory for living where nobody really intrudes' (Ott, $M$ from C, 1982).

Thus, community relations can be perceived via movement within a location. However, also moving to a location affects community relations. Yet, not everyone who moves in or owns a property there is included as part of the community. Often, in these cases, the lines are drawn based on residence frequency (permanent or summer resident) or residence history (in-migrant or in-born). In several studies, in-migrants (or incomers), second home-owners and 'native' inhabitants are separated as different groups within a community (Ellingsen, 2017; Gieling et al., 2019). Our data show that these distinctions were really ambiguous, and the notion of a 'native' resident and incomer was fluid. Sometimes, people who had lived in a region for decades, were still considered incomers and though they were leading community activists, their activities could cause confrontations:

... in the village centre the people who are actively organizing things, are predominantly people who are incomers. And the local people are mostly closed people, who don't... who perhaps remember about deportations [Stalinist repressions during 1941 and 1949] or know... I don't know... old things. /.../ The village association, these days, is a place to waste European funds... (Risto, M from A, 1978).

Interestingly enough, Risto was referring to local people as the ones who remember something that had happened more than 70 years ago, before his own birth. In his interpretation, the 'incomers' who were active in organizing village life were 'wasting' European funds, not investing this for the common good.

Depending on context, people who had taken over their grandparents' households were seen as sometimes as migrants, at other locals. In region C, situated closely to Tallinn, the picture was particularly heterogeneous. During different life stages and seasons, people could dynamically change their residence status, living permanently in the location for years but then moving back to town or vice versa. Our data indicated that migration motives could also depend on one's biographical stage. People moved to the countryside after their kids were born (to get support from their parents), or moved to town when taking their teenage kids to training would take up too much time of their lives. Some people moved back to countryside when kids were old enough to stay on their own. At times, people could move to a rural area after retirement. 
In different villages the dynamics of the relations between incomers and locals was different. While some stressed the importance of descent and brought out the bright sides of being a local and knowing local context and social relations, Katrin ( $F$ from $B, 1964)$ was far more critical towards locals:

My conviction is that the local... /.../ can be sometimes the destroyer of the village life. /.../The people with roots are often relatives to each other. And /.../ all these stories, who has knocked someone's neighbour's wife up, /.../ and these issues broaden and when you are in the village then you have to take one side or another, it is not possible to stay neutral. And .... and then the summer resident... he comes and he is not tied to anyone, he does not have to think.../.../ he is open. (Katrin)

In Katrin's village, several summer residents had chosen to live permanently in the region. Katrin herself had married into the community thirty years ago and stressed her status as an incomer. She was fairly open and struggled to include as many incomers as possible. In the community, thus, many who had moved in rather recently were active there. According to Katrin, the key to their activism was that many families moved in within a fairly short time period together and thus it was easier for them to act together.

\subsection{Social infrastructures shaping mobilities and communities}

It is hardly any surprise that school, shops, and other facilities determine the routes of the community and such infrastructures form important factors in why families choose to move in (or stay) in the countryside. However, not much attention has been paid to how mobilities to and from the social institutions influence community relations, and, what community mobility practices can be influenced by social infrastructures besides the obvious time it takes to reach the destinations.

One of such important social institutions is school. School can be a heart of rural community in many ways. It is often suggested that small community schools provide children with a homely atmosphere, personal approach, and friendly relations. Besides the social contacts between the children, school enables and boosts social relations in a wider community as well, creating friendships among the parents. Sometimes, the need to take kids to hobby classes in towns created groups of people who shared this responsibility - so the kid's hobby affected the social relations of the parents. It could happen also the other way round - that people who already knew each other decided to choose the same hobby class for their children, so the parent's social relations influenced the out-of-class activities of the kids. In A, where the school was closed, Siim ( $M$ from $A, 1979$ ) felt that school had been more than just a site for education:

There is much less social communication, in old times, as I have understood, there were events and the community communicated more with each other. When there was a school in the village, the kids went to school and everybody knew everyone, /.../ but now everyone is on their own. (Siim)

Sirje ( $F$ from $B$, 1967) pointed out that in places where a school is nearby, there is also 'village intelligentia': the teachers. For her, teachers who live nearby schools are cultivating certain values that hold the community together and if this was lost, the community also loses a valuable segment of people.

As schools' survival depends on the number of students, the municipal units are also struggling to be attractive to parents in different ways. Mati (M from B, 1983), who was a member of local municipal body before the unification of the parishes, explained the municipal decisions that were made to increase the number of students at local school. First, he stated that the school bus schedule was designed to attract kids who might go to alternative schools. School bus routes were reorganized to make it comfortable to reach school so that parents whose work route did not pass the school would still consider village school for their kids. The quality of the roads played a part, as well. Due to a lousy quality of the road (gravel), many people who went to the town to work used another way, which, albeit longer, was asphalt and passed the rural school. Mati confessed that the municipality deliberately avoided asphalting the other road in the fear that parents would change the trajectory to work, and would consider putting their kids in a school in 
a nearby town. In addition, they added a school bus to a nearby village (12 km away) which actually had a school of its own. These logistical solutions show that school can shape not only the mobility practices of parents and kids, but also infrastructure in the region in general and movements within community.

Though in many ways being a tool for networking and enhancing social relations, school can also draw borders and create exclusive practices which separate people. When talking about community borders, Mati recalled that during his youth, the numbers of pupils diminished in his own school and neighbouring ones, so that it was not possible any more to organize competitions:

During my school years, there were no sporting competitions anymore [with neighbouring school], /.../ and this created a precondition that I can communicate with [the people from neighbouring village] freely. But people who were some years older than me, my schoolmates, they attended different competitions /.../, which were even actually cool, but on another hand, it created certain barriers between people. I don't have them. (Mati)

According to Mati, these tensions still exist in communication between the older ones.

Local village community centres, libraries, and local shops emerged in the interviews as important socio-materialities influencing mobilities and communities as well, shaping the routes of community members. Many interviewees voiced the need for a mutual physical space to enhance community coherence. The absence of such a space could also foster social relations community activism was empowered by creating such a space. Katrin speculated that since the nearby village centre had a school, shop, cultural house, and sporting facilities, the community activism was weak there, as people already had everything nearby and had no need to mobilize in the name of some mutual goal. By contrast, her own village had no mutual gathering space a decade ago and so they started to organize a renovation of an old fishermen club, which later became the centre of community life. Though her evaluation for the nearby village community life might have been speculative, the need for mutual physical space was indeed something that came up in other interviews as well. However, this space does not necessarily have to be a house. Tauno (M from C 1967) recalled the priorities of the village association after it was formed:

The first issues we dealt with was the village and ordering of village space. For instance, this area around the village pond, we decided to clean and clear it up and had to organize that it was rented for free to the village association. It previously belonged to the state. We organized this. (Tauno)

Much of the success of such actions that Tauno describes owes to European Union funds, such as LEADER. These funds can be applied via some juridical body, which commonly is an NGO of the village association. ${ }^{3}$ Managing this juridical body and skills for applying funds like LEADER (most common source for such activities) are not available for many in rural areas. Often, middleclass in-migrants can become organizers of such activities, causing reluctance to accept the changes among those who have been living there for longer periods (cf Risto's quote in previous subchapter). However, sometimes just different organizational issues can cause confrontations. Janek (M from B, 1980) commented:

... we were thinking that... at different places, where in villages people have built village houses, then for some reason the local community has picked up a fight, several different opposing sides emerge... sometimes even three or more. But as in [our] village, nothing is organized, then everything is alright, people do not fight (laughs) (Janek).

However, Janek and his wife were active in community life in many ways. Janek was taking part in a local band and singing ensemble, went to nearby cultural house, for sports and his wife was attending another music collective. It is notable, however, that these activities made him and his family rather mobile, as the ensembles they attended were situated $25 \mathrm{~km}$ from their home village, and sporting facilities $10 \mathrm{~km}$ away to an opposite direction. This distance enabled them to keep away from intrigues of other villages, but still be part of these communities occasionally, participating in the activities they chose. And though Janek indicated that he did not feel the need

\footnotetext{
${ }^{3}$ LEADER funds are applied through local municipalities.
} 
to have a village association house in his home village, he still needed these activities, which eventually affected his mobility practices.

\subsection{Social and material borders of communities}

The borders of the communities are dynamically changing, being intertwined with material, legal, and social structures. This is well exemplified on the micro-level by Risto's story. In his home area, there was an historical old forest road leading to a lake used by the locals. People used to go swimming via this path for as long as Risto remembered and knew local stories. However, once when he transported some wood through this road, an owner, who moved to the area in the 1980s, stood on the path and forbid his passing by, appealing to the legal status of the land (private property). The conflict escalated to a level when the owner dug a ditch crossing the road so that it is now impassable. This ditch is very material, but also symbolic - it is a ditch that denies access to the road and changes mobility practices inside a community, but also creates invisible social borders within the same community. In a way, this ditch emerged due to the change in state order. During the Soviet time it belonged to a collective farm, i.e community, and later, its privatization affected both social relations and mobility practices.

The tensions that private roads and private land caused came up in other interviews as well (e.g., Kätlin in the previous subchapter). Sirje said how the change of ownership of a common site for the yearly Midsummer night's party ${ }^{4}$ eventually led to changing the party site, as the owner did not take care of the site and it turned inappropriate. However, the new site was also on private property:

Then the mid-summer's night bonfire moved in the midst of the village, which was actually also private land. And as it was situated close to someone's backyard, then some people felt it was kind of a private party there... and were reluctant to go there (Sirje).

This extract shows that even though the owner did not draw borders in the landscape and enabled access to his land, the sense of private ownership created unseen borders within the community symbolically, but also affected mobility practices, as people started to visit other sites in neighbouring villages for the occasion.

Such symbolic borders can be created also by types of buildings or village spatial organization. For instance, during the Soviet time, blocks of flats were built into village centres to symbolize the modernisation of the rural and blur the borders of urban/rural settlements (Kurg, 2019). After the re-independence of Estonia, the decrease in rural population, and the changes in the symbolic meaning of the rural, many of these housing units remained scarcely inhabited and thus, deteriorated over the years. According to Statistics Estonia, by 2050, in several parts of Estonia 5,300 blocks of flats-type of houses will be abandoned. Some of our cases show that the block of flats, which were built in the Soviet period for the kolkhoz workers, created ambiguous feelings about their belonging to the rural landscape. In area of $A$, some block of flats were turned into social housing by the municipality at the turn of the $21^{\text {st }}$ century. This triggered a wave of migration of new people who struggled with social problems. In the process they formed a new, particular community within the village. This was brought out by Siim, who moved to the area in 2013:

This social housing is situated there, the inhabitants segment is changing there... so... It seems that establishing a social housing in a village is not very sensible, as the people are not local, you see. There are no jobs here. They have no transportation on their own, so you have to organize transport for them and there has to be a bus and... In general, their life would be easier in a city, where all the services are available. Right now, these people are brought here, into a social housing. And they have no self-realization here (Siim).

Though the social segment in this house is slowly changing, this house still contradicts people's idea of rural idyll according to our informants and is separated from the local community. By contrast, in area $B$, blocks of flats as living environments were highly valued, mainly because of economic reasons. Often young people who moved out from their parents' house needed

\footnotetext{
4 The Midsummer's night festivities will be described later.
} 
a private but affordable space to live nearby their parents, or elderly people who needed the infrastructures to be close, inhabited the apartments. Several informants said that it was hard to acquire the apartment in this particular region. Though the inhabitants of these houses were not seen as being outside the community, still many informants confessed that living in such a house contradicts their idea of rural life.

The aforementioned administrative reform united several municipalities, causing the change in governance structures in villages and creating new administrative units (e.g. neighbourhood or kant in Estonian). In many cases, this brought forth also the change in municipality borders. Often, the enlarged municipality increased budget and new opportunities in local development in terms of investments in houses, wireless connection, road management, and public transport, enabling better access to schools, childcare or shops. All these developments shaped or moulded also mobility practices of the community.

In area $\mathrm{C}$, many interviewees hoped that the improved financial situation due to the reform could attract new inhabitants, and the increased population would give their region better chances of representation in the new municipal government. However, not everybody was in favour of the population increase. For instance, Tauno feared that this would threaten the village's status as a 'traditional sparsely populated area'. According to him, a high population rate is an urban phenomenon and eventually weakens community ties. This leads to a paradox of strong and weak community ties: a strong community can be exclusive yet with shared values and mutual identity, while weak ties in a community can foster building bridges and makes the community inclusive (Granovetter, 1973; Shucksmith, 2018).

Several interviewees indicated that after the reform, the village borders were not that strongly perceivable anymore, also changing how the borders of the communities were sensed. Often, the informants confessed that within the smaller borders of municipality, the sense of place and community within this place was easier to identify with. After the regional reform, there have been efforts to create some smaller regional units. However, these have not always been successful in terms of people identifying with them. Riho (M from C, 1954) complained that previously, people knew where they belonged and the new reform jeopardized this. He exemplified this by bringing example of sports competitions:

When you go and ask a person to join a sport competition, then a question emerges, for who? In the name of neighbourhood, you see. /... What the hell. Village was village and neighbourhood is neighbourhood, but... Well the ones who are dedicated sportsmen, they still go, but the others... Bleak, very bleak (Riho).

This was also illustrated by the story of Ivo (from A), who wanted to restore a village's old name,but found weak support for his cause in the community. Ivo was so disappointed that he expressed this by saying those who did not support the cause had 'sold' the village.

One of the phenomena which illustrates the blur borders of the communities in Estonian context, is the celebration of Midsummer's Night. Besides Christmas, this is one of the national festivities that is widely celebrated and considered important. Though this definitely can be a private and closed event with friends and family, village communities often organize a communal party with a bonfire and different activities (e.g., live music, games etc). As different villages host this party, the party schedules are flexible and within one region, different parties are held at different days so people can attend many in the region. Some people we interviewed visited three to five bonfires within two or three days. However, depending on the person, the area of these parties differed significantly - one neighbour visited the parties that happened west of the village, another went to party in the east. This indicates that due to increased mobility options, people can now choose the location they want to contribute in terms of community life, even if the place is tens of kilometres away from their home. Besides Midsummer's Night, other celebrations could also mean visiting villages further away. Sometimes, a certain combination of village communities can emerge. For instance, in region $B$, two villages which were approximately $18 \mathrm{~km}$ away from each other had different celebrations together, though there were other villages much closer to each of them. The reasons for this were complex, but mainly had to do with social connections which were rather occasional in character. Thus, the lines of rural communities are often arbitrary and not particularly easy to draw on the map. 


\section{Discussion and conclusion}

In this article, we analyzed communities in Estonian scarcely populated areas applying the new mobilities paradigm (Sheller \& Urry, 2006). We found this paradigm very useful, particularly in terms of revealing the dynamics of community processes in these types of settlements. Besides the community development processes, it helped to shed light on the importance of everyday materialities (Bell et al., 2010), their meanings in these dynamics, and the impact of mobilities on social relations and hierarchies (Halfacree \& Rivera, 2012; Hunt, 2019). Material objects, such as buildings (school, library, block of apartments), village roads or border signs, and their social or physical transformation (e.g. closing schools or renovating local roads), can shape social relations and everyday mobility practices and vice versa: mobilities shape and mould the landscape around the community. The new mobility paradigm helped to bring forth the role of personal biographies and life stages in community dynamics (Mettenberger \& Küpper, 2019), but also how the changing socio-political situation can shape choices on both personal and community levels (Coulter et al., 2016).

We showed that individual and collective representations of the rural and urban play important roles in shaping local community relations. People have certain ideas about rural (mundane) mobilities (Edensor, 2007) and this was actively also imposed on how community relations should be (re)arranged (for instance, the idea of free movement on neighbour's fields). These representations also have a more personal, self-oriented level. People need these representations to be reflexive about their biographical choices (to live in the countryside or to leave it, cf Coulter et al., 2016). Sometimes, people need to create distinction with urban/rural life in order to make sense of their everyday practices even if these representations are contradictory. For instance, people may conceptualize rural life as idyllic, free, and peaceful, though their daily routines do not enable them to have more free time compared to their lives in town.

The representations of rurality did not always coincide among different members of community and this could cause tensions. People from middle class urban backgrounds with enough social and cultural capital to apply for EU funds could organize village community life according to their ideas of what rural is, thus potentially creating confrontations (Savage et al., 2005; cf Creamer et al., 2019, p. 949). Different understandings of what is rural is may also bring along diverse and individualized attitudes towards the area (Bossuet, 2006; Granovetter, 1973). The vision of how to (re)arrange local cultural and symbolic meanings and materialities of the area may be a kind of place branding (Argent, 2019, p. 759), which invites new meanings that attract new inhabitants to the region (Gieling et al., 2019). These aspects illustrate the paradox well. Shucksmith (2018, p. 167) has pointed to - rural communities can be both inclusive and exclusive and strong borders of community feeling may draw borders in landscape which are not necessarily enhancing networking relations with neighbours. Every border both unites and separates. Yet, according to our study, these confrontations were not necessarily always based on the urban/rural (incomer/native) scale as, having a closer look to community relations, these lines themselves blurred. Also, these tensions are not necessarily negative, as they enable to form new networks and help communities adjust and meet contemporary socio-political demands (Hidle et al., 2010).

The new mobility paradigm brought forth the importance of social and physical infrastructures in shaping the community relations. The absence of a community centre may both enhance community development (people start to create one and thus find mutual commitment and shared identity in fighting for one cause) as well as jeopardize good relations (as applying financial resources and managing the house can cause conflicts). The absence of such materialities may be negative for social cohesion as people might not communicate with one another, but positive, as they have no source of conflicts. Yet, one has to be aware that community can be united by other spatial and material phenomena, by a quest to order surrounding landscape, such as a park, riverside, benches or mutual fight for light traffic road. Through these infrastructures, the social, institutional, and legal issues that shape community relations are intertwined. All these processes are also closely connected to mobilities - people's potential to attend village activities (including access to mobility, cf Kaufmann, 2004), but also how ordered spaces and landscapes attract people from either neighbouring villages to attend the events organized there, or people moving 
in (either buying second home or primary residence). These processes are not necessarily smooth, and certain social hierarchies play a role here, thus social inequalities may sometimes be reproduced by this (Savage, 2010).

Our research indicated that the community borders that frame village units, though blurring and shifting within community and contextually among individuals, are still important on many levels. The village borders are often intertwined with narratives of the past and the personal relations to the land. However, the institutional changes of borders can shape the bordering practices in many ways, though not always along the same lines with administrative borders. Sometimes, the place identity and its boundaries get dissolved with the changes, at other times the community borders within bigger borders get tightened, as people want to distinguish their old borders within the new ones. We examined how mobility broadens the borders, yet many people still need a kind of regional, i.e. material body and institutional form to identify with. These institutional labels or names in general might not be important for all, thus potentially also causing tensions within community.

Mettenberger and Küpper (2019, p. 756) have indicated how people with 'spatial mobility and supra-regional social interactions'may not be regarded as a part of a local community, but from the lens of new mobilities paradigm, our study suggests that such relations can become important for local community sustainability. Widening the community or administrative borders in community management enables to find people with social skills connected to different sociopolitical networks in the urban region. This indicates that the urban/rural linkage is working on multiple levels in rural development (Bock, 2016), which stresses that neither top-down (urban to rural) nor bottom-up (rural to urban) models of rural development are as effective as their intertwining. Such networks are important in enabling better access to education or adapting to a political and economic change (Bock, 2016, p. 568). Social and political formations have brought forth new social borders that can also affect different materialities. For instance, the change in legal status (private land ownership changes) can affect the trajectories of everyday movements and shape community relations when roads that have been used often are suddenly blocked or closed.

Though rural communities are closely tied to stable everyday lives, they are constantly on the move and shifting. It is important to note and follow the dynamics in these, as these dynamics become important also in preserving and maintaining these communities. These layers may not be visible at a first glance, yet, these are crucial in terms of vitality of a community. It is important to pay attention to different kinds of practices, such as commuting or negotiating everyday patterns of new inhabitants into socio-cultural environment of the (existing) community. Paradoxically, even though these patterns and the socio-materialities of communities are on a constant move, the representation of a rural community as a stable unit is an important symbolic resource, both in social and spatial place identity.

\section{Acknowledgements}

This research was supported by Estonian Research Agency (Grant no PRG 398). The authors also thank the anonymous reviewers for their valuable comments.

Academic references

[1] Alanen, I. (1999). Agricultural policy and the struggle over the destiny of collective farms in Estonia. Sociologia Ruralis, 39 (3): 431-458. DOI: 10.1111/1467-9523.00117.

[2] Alanen, I. (2004). The transformation of agricultural systems in the Baltic countries A critique of the World Bank's concept. In Alanen, I., ed., Mapping the rural problem in the Baltic countryside. Transition processes in the rural areas of Estonia, Latvia and Lithuania (pp. 5-57). Aldershot: Ashgate.

[3] Annist, A. (2011). Otsides kogukonda sotsialismijärgses keskuskülas. Arenguantropoloogiline uurimus. Tallinn: Tallinn University Press. 
[4] Argent, N. (2019). Rural geography III: Marketing, mobilities, measurement and metanarratives. Progress in Human Geography 43(4), 758-766. DOI: $10.1177 / 0309132518778220$.

[5] Barrett, G. (2015). Deconstructing community. Sociologia Ruralis 55, 182-204. DOI: $10.1111 /$ soru.12057.

[6] Bauman, Z. (2001). Community. Seeking safety in an insecure world. Cambridge: Polity Press.

[7] Bell, M. M., Lloyd, S. E. \& Vatovec, C. (2010). Activating the countryside: Rural power, the power of the rural and the making of rural politics. Sociologia Ruralis 50(3), 205-224. DOI: 10.1111/j.1467-9523.2010.00512.x.

[8] Blackshaw, T. (2010). Key concepts in community studies. London: Sage.

[9] Bock, B. B. (2016). Rural marginalisation and the role of social innovation; A turn towards nexogenous development and rural reconnection. Sociologia Ruralis 56(4), 552-573. DOI: $10.1111 /$ soru.12119.

[10] Bossuet, L. (2006). Peri-rural populations in search of territory. Sociologia Ruralis 46(3), 214-228. DOI: 10.1111/j.1467-9523.2006.00410.x.

[11] Castells, M. (1996). The rise of the network society. Oxford: Blackwell.

[12] Cohen, S. A., Duncan, T. \& Thulemark, M. (2015). Lifestyle mobilities: The crossroads of travel, leisure and migration. Mobilities 10(1), 155-172. DOI: $10.1080 / 17450101.2013 .826481$.

[13] Coulter, R., van Ham, M. \& Findlay, A. M. (2016). Re-thinking residential mobility: Linking lives through time and space. Progress in Human Geography 40(3), 352-374. DOI: $10.1177 / 0309132515575417$.

[14] Creamer, E., Allen, E. \& Haggett, C. (2019). 'Incomers' leading 'community-led' sustainability initiatives: A contradiction in terms? Environment and Planning C: Politics and Space 37(5), 946-964. DOI: 10.1177/0263774X18802476.

[15] Cresswell, T. (2010). Mobilities I: Catching up. Progress in Human Geography 35(4), 550 558. DOI: $10.1177 / 0309132510383348$.

[16] Cresswell, T. (2012). Mobilities II: Still. Progress in Human Geography 36(5), 645-653. DOI: $10.1177 / 0309132511423349$.

[17] Cresswell, T. (2014). Mobilities III: Moving on. Progress in Human Geography 38(5), 712721. DOI: $10.1177 / 0309132514530316$.

[18] Delbosc, A. \& Currie, G. (2011). The spatial context of transport disadvantage, social exclusion and well-being. Journal of Transport Geography 19(6), 1130-1137. DOI: 10.1016/j.jtrangeo.2011.04.005.

[19] Edensor, T. (2006). Performing rurality. In Cloke, P. Marsden, T. \& Mooney, P. eds., Handbook of Rural Studies (pp. 484-95). London: Sage. DOI: 10.4135/9781848608016.n35.

[20] Edensor, T. (2007). Mundane mobilities, performances and spaces of tourism. Social \& Cultural Geography 8(2), 199-215. DOI: 10.1080/14649360701360089.

[21] Ellingsen, W. (2017). Rural second homes: a narrative of de-centralisation. Sociologia Ruralis 57(2), 229-244. DOI: 10.1111/soru.12130.

[22] Fallov, M. A., Jørgensen, A. \& Knudsen, L. B. (2013). Mobile Forms of Belonging. Mobilities 8(4), 467-486. DOI: 10.1080/17450101.2013.769722.

[23] Frello, B. (2008). Towards a discursive analytics of movement: On the making and unmaking of movement as an object of knowledge. Mobilities 3(1), 25-50. DOI: 10.1080/17450100701797299. 
[24] Giddens, A. (1991). Modernity and self-identity: self and society in the late modern age. Palo Alto: Stanford University Press.

[25] Gieling, J., Vermeij, L. \& Haartsen, T. (2017). Beyond the local-newcomer divide: Village attachment in the era of mobilities. Journal of Rural Studies 55, 237-247. DOI: 10.1016/j.jrurstud.2017.08.015.

[26] Gieling, J., Haartsen, T., Vermeij, L. \& Strijker, D. (2019). Out of love for the village? How general and selective forms of attachment to the village explain volunteering in Dutch community life. Journal of Rural Studies 71, 181-188. DOI: 10.1016/j.jrurstud.2018.06.008.

[27] Goodwin-Hawkins, B. (2015). Mobilities and the English village: Moving beyond fixity in rural West Yorkshire. Sociologia Ruralis 55(2), 167-181. DOI: 10.1111/soru.12043.

[28] Granberg, L. (2004). From agriculture to tourism: constructing new relations between rural nature and culture in Lithuania and Finland. In Alanen, I., ed., Mapping the rural problem in the Baltic countryside. Transition processes in the rural areas of Estonia, Latvia and Lithuania (pp. 159-178). Aldershot: Ashgate.

[29] Granovetter, M. S. (1973). The strength of weak ties. American Journal of Sociology, 78(6), 1360-1380.

[30] Halfacree, K. (2012). Heterolocal identities? Counter-urbanisation, second homes, and rural consumption in the era of mobilities. Population, Space and Place 18(2), 209-224. Doi: 10.1002/psp.665.

[31] Halfacree, K. H. \& Rivera, M. J. (2012). Moving to the countryside... and staying: Lives beyond representations. Sociologia Ruralis 52(1), 92-114. DOI: 10.1111/j.14679523.2011.00556.x.

[32] Hampton, K. \& Wellman, B. (2001). Long distance community in the network society: Contact and support beyond netville. American Behavioral Scientist 45(3), 476-495. DOI: $10.1177 / 00027640121957303$.

[33] Hidle, K., Ellingsen, W. \& Cruickshank, J. (2010). Political conceptions of second home mobility. Sociologia Ruralis 50(2), 139-155. DOI: 10.1111/j.1467-9523.2010.00508.x.

[34] Hsieh, H.-F. \& Shannon, S. E. (2005). Three Approaches to Qualitative Content Analysis. Qualitative Health Research 15(9), 1277-1288. DOI: 10.1177/1049732305276687.

[35] Hunt, R. (2019). Neglected rural geography: Exploring the quiet politics of 'out-dwelling'. Environment and Planning C: Politics and Space 37(2), 219-236. DOI: $10.1177 / 2399654418784944$.

[36] Irwin, M. D. (2016). The concept of community as theoretical ground: Contention and compatibility across levels of analysis and standpoints of social processes. In Abrutyn, S., ed., Handbook of Contemporary Sociological Theory (pp. 247-268). Memphis: Springer.

[37] Jetzkowitz, J., Schneider, J. \& Jetzkowitz, S. B. (2007). Suburbanisation, mobility and the 'good life in the country': A lifestyle approach to the sociology of urban sprawl in Germany. Sociologia Ruralis 47(2), 148-171. DOI: 10.1111/j.1467-9523.2007.00431.x.

[38] Juska, A., Poviliunas, A., Ziliukaite, R. \& Geguziene, V. (2008). Rural intelligentsia and path dependency in post-socialist civic organising: The Case of Lithuania. Sociologia Ruralis 48(2), 93-117. DOI: 10.1111/j.1467-9523.2007.00454.x.

[39] Kasemets, K., Rammo, A. \& Palang, H. (2019). Turning a landscape into a suburban community and the realization of a sense of place. Cities 88 37-47. DOI: 10.1016/j.cities.2019.01.012.

[40] Kaufmann, V., Bergman, M. M. \& Joye, D. (2004). Motility: Mobility as capital. International Journal of Urban and Regional Research 28(4), 745-756. DOI: 10.1111/j.03091317.2004.00549.x. 
[41] Kay, R. (2012). Managing everyday (in)securities: Normative values, emotional security and symbolic recognition in the lives of Russian rural elders. Journal of Rural Studies 28(2), 6371. DOI: 10.1016/j.jrurstud.2012.01.018.

[42] Kurg, A. (2019). Werewolves on Cattle Street: Estonian collective farms and postmodern architecture. In Kulic, V., ed., Second World postmodernisms: Architecture and society under late socialism (pp. 111-127). London: Bloomsbury.

[43] Maclaren, A. S. (2017). Affective Lives of Rural Ageing. Sociologia Ruralis 58(1), 213-234. DOI: $10.1111 /$ soru.12196.

[44] Massey, D. (2005). For Space. London: Sage.

[45] Meador, J. E. (2019). Reaching rural: Identifying implicit social networks in community development programmes. Journal of Rural Studies 68, 285-295. DOI: $10.1016 /$ j.jurstud.2018.12.006.

[46] Mettenberger, T. \& Küpper, P. (2019). Potential and impediments to senior citizens' volunteering to maintain basic services in shrinking regions. Sociologia Ruralis 59(4), 739 762. DOI: $10.1111 /$ soru.12254.

[47] Milbourne, P. \& Kitchen, L. (2014). Rural mobilities: Connecting movement and fixity in rural places. Journal of Rural Studies 34, 326-336. DOI: 10.1016/j.jrurstud.2014.01.004.

[48] Mormont, M. (1990). Who is rural? Or, how to be rural: Towards a sociology of the rural. In Mardsen, T., Lowe, P. \& Whatmore, E., eds., Rural restructuring: Global processes and their responses. London: David Fulton.

[49] Navarro, F. A., Woods, M. \& Cejudo, E. (2015). The LEADER Initiative has been a victim of its own success. The decline of the bottom-up approach in rural development programmes. The cases of Wales and Andalusia. Sociologia Ruralis 56(2), 270-288. DOI: 10.1111/soru.12079.

[50] Nugin, R. (2018). Mobile lives, immobile representations: Why mobility is not part of rural representation. Transfers 8 (2), 87-112. DOI: 10.3167/TRANS.2018.080206.

[51] Nugin, R. \& Palang, H. (2020). Borderscapes in landscape: Identity meets ideology. Theory \& Psychology. DOI: 10.1177/0959354320948131.

[52] Putnam, R. D. (2000). Bowling alone: The collapse and revival of American community. New York: Simon \& Schuster.

[53] Raagmaa, G. \& Stead, D. (2014). Spatial planning in the Baltic states: Impacts of European policies. European Planning Studies 22(4), 671-679. DOI: 10.1080/09654313.2013.772730.

[54] Roche, M. (2002). Rural geography: searching rural geographies. Progress in Human Geography 26(6), 823-829. DOI: 10.1191/0309132502ph406oa.

[55] Rodman, M. C. (1992). Empowering Place: Multilocality and Multivocality. American Anthropologist 94(3), 640-656. DOI: 10.1525/aa.1992.94.3.02a00060.

[56] Ruutsoo, R. (2004). Rural Communities in the Baltic States and Post-Communist Transition. In: Alanen, I., ed., Mapping the rural problem in the Baltic countryside. Transition processes in the rural areas of Estonia, Latvia and Lithuania (pp. 59-107). Aldershot: Ashgate.

[57] Savage, M., Bagnall, G. \& Longhurst, B. (2005). Globalization and belonging. London: Sage.

[58] Savage, M., Allen, C., Atkinson, R., Burrows, R., Méndez, M.-L. \& Watt, P. (2010). Focus article. The politics of elective belonging housing. Theory and Society 27(2), 115-161. DOI: $10.1080 / 14036090903434975$.

[59] Sepp, V. \& Noorkõiv, R. (2018). Haldusreformi kesksete kriteeriumite valik: kuidas tuli 5000 ja 11000 elaniku nõue. In Valner, S., ed., Haldusreform 2017. Artiklikogumik (pp. 123-160). Tallinn: Print Best. 
[60] Sheller, M. \& Urry, J. (2006). The new mobilities paradigm. Environment and Planning A: Economy and Space 38(2), 207-226. DOI: 10.1068/a37268.

[61] Shucksmith, M. (2018). Re-imaging the rural: From rural idyll to Good Countryside. Journal of Rural Studies 59, 163-172. DOI: 10.1016/j.jrurstud.2016.07.019.

[62] Tomaney, J. (2015). Region and place II: Belonging. Progress in Human Geography 39(4), 507-516. DOI: 10.1177/0309132514539210.

[63] Woods, M. (2010). Performing rurality and practising rural geography. Progress in Human Geography 34(6), 835-846. DOI: 10.1177/0309132509357356.

[64] Woods, M. (2011). Rural. London: Routledge.

Other sources

[65] Tamm, M. \& Nergi, A. M. (2018). Tallinn autostub. Eesti Ekspress 29(42) Available online at http://longread.delfi.ee/artiklid/tallinnasse-voorib-iga-paev-juurde-50-000-autot-linn-jaabneile-kitsaks? id=83978754. Accessed Dec 2020. 